\title{
Lycopene: From Plants to Humans
}

\author{
J.K. Collins and P. Perkins-Veazie \\ U.S. Department of Agriculture, Agriculture Research Service, South Central Agriculture Research Laboratory, \\ Lane, OK 74555 \\ W. Roberts \\ Wes Watkins Agricultural Research Center, Lane, OK 74555
}

Additional index words. varotenoid, tomato, watermelon, bitter melon, red grapefruit, gac, epidemiology, cancer

\begin{abstract}
Lycopene is a pigment that imparts a red or red-orange color to some fruits and vegetables. This carotenoid has been extensively studied over the last 10 years because of its potent antioxidant activity and medical evidence that dietary intake can reduce the incidence of cardiovascular disease and some cancers. The purpose of this review is to provide researchers in the areas of horticulture and food science a current summary of available information on lycopene in plants, stabilization and extraction, and potential health benefits as delineated in current medical studies.
\end{abstract}

\section{Lycopene Synthesis}

Lycopene is one of $\approx 600$ carotenoids naturally found in plants, bacteria, fungi, and algae (Jones and Porter, 1999). Like other carotenoids such as lutein and beta-carotene, lycopene has dual roles in humans and plants as a free-radical scavenger (Jones and Porter, 1999). In plants, lycopene confers antioxidant protection for photosystem events and appears in chromoplasts during ripening, and is speculated to improve attraction, consumption, and seed dissemination by herbivores (HorneroMendez and Britton, 2002; Ronen et al., 1999). In humans, lycopene is thought to act by scavenging singlet oxygen and peroxy radicals and deactivating excited molecules or DNA chain-breaking agents (Stahl et al., 1997).

Carotenoids can be synthesized in bacteria, algae, fungi, and green plants, and currently two synthesis pathways have been found (Sandmann, 2001). In fungi, carotenoids are derived through the mevalonic acid (MVA) pathway (Sandmann, 2001). In plants, the independent pathways MVA and methylerythritol phosphate (MEP) synthesize the fivecarbon units isopentenyl diphosphate (IPP) and its isomer, diethylallyl diphosphate (DMAPP), needed as precursors for carotenoids (Botella-Pavia et al., 2004). It is thought that plant carotenoids synthesized in chloroplasts and chromoplasts arise primarily from the MEP pathway (Botella-Pavia et al., 2004). Three molecules of IPP and one of DMAPP plus the presence of geranylgernanyl diphosphate synthase forms geranylgeranyl diphosphate (GGPP), a molecule used in several pathways, including carotenoids. Two molecules of GGPP (2 C20 molecules) form

Received for publication 3 Mar. 2006. Accepted for publication $2 \mathrm{Apr}$. 2006. Mention of trade names or commercial products in this article is solely for the purpose of providing specific information and does not imply recommendation or endorsement by the U.S. Department of Agriculture. All programs and services of the U.S. Department of Agriculture are offered on a nondiscriminatory basis without regard to race, color, national origin, religion, sex, age, marital status, or handicap. The article cited was prepared by a USDA employee as part of his or her official duties. ${ }^{1}$ To whom reprint requests should be addressed; e-mail jcollins-usda@lane-ag.org. phytoene (C40 molecule) from head-to-head condensation (Jones and Porter, 1999; Sandmann, 2001) (Fig. 1). Phytoene is converted into zeta carotene by phytoene desaturase and lycopene is converted from zeta carotene by zeta carotene desaturase (Sandmann, 2001). From lycopene, the pathway is split and cyclization of lycopene can occur at one or both ends to form monocyclic (delta-carotene and gamma-carotene) and dicyclic compounds (alpha carotene and beta carotene) (Fig. 1). Although the general synthesis of carotenoids has been extensively researched, the regulatory enzymes involved in controlling carotenoid synthesis in plants are not completely understood (Fraser et al., 2001). Structurally, lycopene is an unsaturated hydrocarbon with an isoprenoid polyene chain structure made up of 40 carbons and 56 hydrogen molecules (Ronen et al., 1999). It has 11 conjugated and two nonconjugated double bonds and lacks the beta-ionone ring structure that can be enzymatically converted into vitamin A (Yeh and $\mathrm{Hu}, 2000$ ).

\section{Plant Sources of Lycopene}

Common plant sources of lycopene in the Western diet are tomatoes (Lycopersicon esculentum), processed tomato products, watermelon (Citrullus lanatus), Brazilian guava (Psidium guajava), and red grapefruit (Citrus paradisi) (Tables 1 and 2) (Holden et al., 1999). Other plant sources not normally consumed in the United States but now being considered as a source for nutraceutical lycopene use include autumn olive (Eaeleagnus angustifolia), red carrots (Daucus sp.), rose hips (Rosaceae sp.), bitter melon, and gac fruit (Mormidica sp.) (Fordham et al., 2001; Ishida et al., 2004; Nguyen and Schwartz, 1998; Yen et al., 1981) (Table 1). Some spices and condiments such as salad dressings that contain tomato sauce also provide minute amounts of lycopene (Table 2). Lycopene occurs as cis or trans isomers and is readily identified in foods using high-performance liquid chromatography (Khachik et al., 1995). Guides for carotenoid analysis in foods, including extraction and detection methodologies, have been published (Craft, 2001; Fish et al., 2002; RodriguezAmaya, 2001), and rapid spectrophotometric methods have been developed for watermelon and tomatoes (Davis et al., 2003). In tomatobased foods, $79 \%$ to $91 \%$ of the lycopene is in the trans form and $9 \%$ to $21 \%$ is in the cis form (Clinton et al., 1996). In red watermelon, trans lycopene predominates at $92 \%$ to $95 \%$ of total lycopene and is the primary carotenoid (Perkins-Veazie et al., 2001). Lycopene cis and trans composition of other foods has not been well characterized.

\section{Genetic Effects}

Tomato germplasm (red fruit) varies from 10 to $150 \mathrm{mg} / \mathrm{kg}$ lycopene (Arias et al., 2000; Dumas et al., 2003; Raffo et al., 2006; Thompson et al., 2000). Red-fleshed watermelon appears to have a carotenoid synthesis pathway similar to tomato (Tadmor et al., 2004), and watermelon germplasm ranges in lycopene content from 30 to $120 \mathrm{mg} / \mathrm{kg}$ (PerkinsVeazie et al., 2001; Perkins-Veazie et al., 2006). Both orange tomatoes and orange watermelons contain small amounts of lycopene $(<5 \mathrm{mg} / \mathrm{kg})$, but none is found in yellow types. Carrot roots can also accumulate lycopene as well as alpha and beta-carotene (Horvitz et al., 2004; Surles et al., 2004). The genes responsible for carotenoid synthesis in carrots are still being identified with an eventual goal to develop carrot germplasm containing $>100 \mathrm{mg} / \mathrm{kg}$ (Santos and Simon, 2002; Phillip Simon, personal communication). Red grapefruit, thought to originate from somatic mutations that occurred in vegetative buds or branches of pale yellow-fruited varieties (Corazza-Nunes et al., 2002), contains 2 to $22 \mathrm{mg} / \mathrm{kg}$ lycopene, depending on variety and production environment (Patil et al., 2004; USDA, 2005a).

Plant-breeding programs have used both traditional and molecular methods to enhance levels of lycopene and other carotenoids in fruits. More breeding research has been conducted with tomato, probably because the visible color changes that occur during fruit ripening help pinpoint changes in carotenoid pigments and enzymes (Ronen et al., 2000). Single-gene color mutants of tomatoes were first documented in the 1940s, resulting from crosses with a normal canning tomato (Lycopersicon esculentum, Mill) and a wild species (Lycopersicon esculentum, Humb) to produce a high beta-carotenecontaining orange fruit (Ronen et al., 2000; 


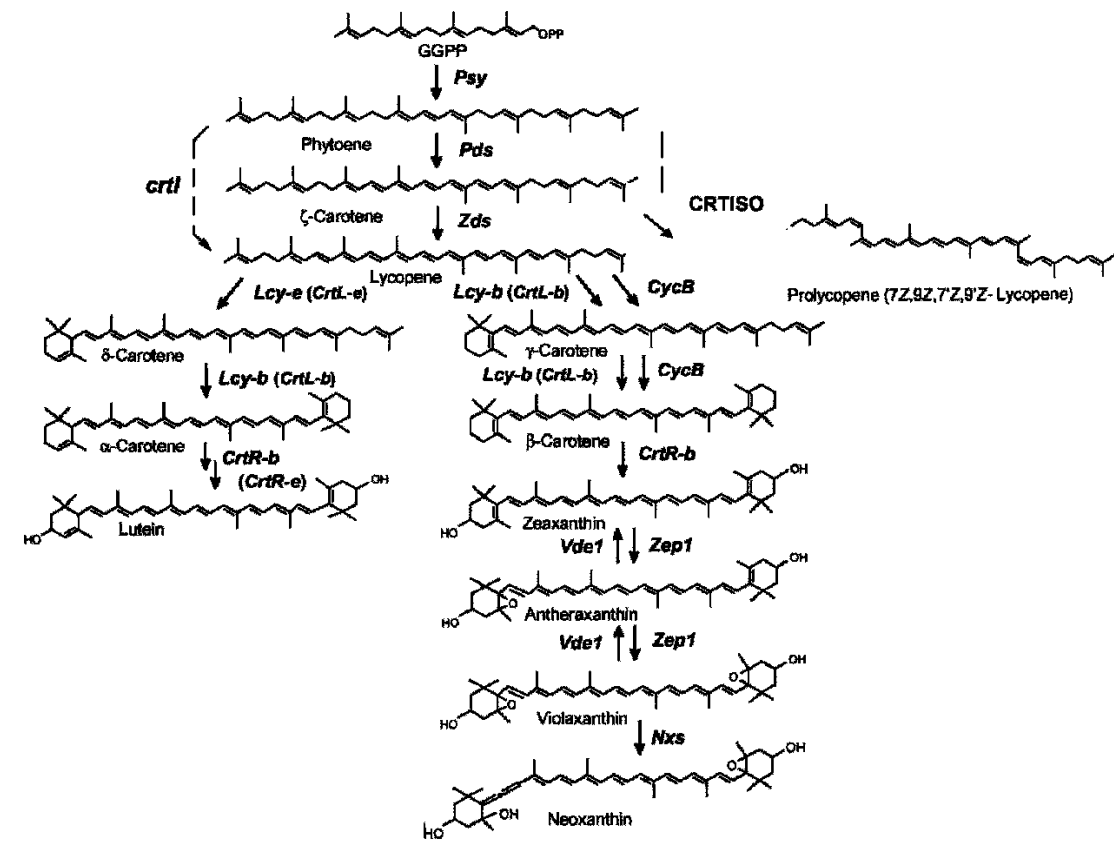

Abbreviations: GGPP $=$ Geranylgeranyl diphosphate, Psy $(\mathrm{crlB})=$ Phytoene desaturase,

Pds $($ crlP) $=$ Phytoene synthase, $Z$ ds $($ crtQ $)=$ Zeta-carotene desaturase, Lyc-e (CTRL-

e) $=$ Lycopene epsilon-cyclase, $\mathrm{CycB}=$ Chromoplast specific lycopene cyclase, Lcy-b

(CtrL-b) $=$ Lycopene B-cyclase, $\mathrm{CRTISO}=$ Carotenoid isomerase, $\mathrm{CrtR}-\mathrm{b}=\mathrm{B}-\mathrm{ring}$

hydoxylase, CrtR-e=Epsilon-ring hydroxylase, Zep 1=Zeaxanthin epoxidase,

$\mathrm{Vda}=$ Violaxanthin deepoxidase, $\mathrm{Nxs}=$ neoxanthin synthase

Figure published with permission: Source: Isaacson et al., 2002.

Fig. 1. Carotenoid biosynthesis pathway.

Tomes et al., 1954). The genes and enzymes controlling carotenoid synthesis in tomatoes have been identified through cloning and molecular characterization (Ronen et al., 2000). Nine genetic loci (15 alleles) controlling color pigmentation have been found, and additional genes may exist (Sacks and Francis, 2001). The crimson gene $\left(\operatorname{og}^{c}\right)$ has been bred into many of the commercial tomatoprocessing materials that are currently used (Thompson et al., 2000). This gene confers an inability to acquire beta-carotene at the same rate as normal red tomatoes $\left(r^{+}\right)$but increases the amount of lycopene that is formed (Mohr, 1979). However, many of the other high-pigment genes are not used in breeding materials because they impart undesirable plant characteristics (i.e., poor germination, brittle stems) (Sacks and Francis, 2001).

\section{Environmental Effects}

Environmental production conditions such as temperature, light, mineral uptake, salinity, and irrigation affect lycopene development in plant materials (Table 3). Changes yellow shoulder in processing tomatoes grown in California (Hartz et al., 1999), implying a role for potassium in lycopene synthesis or degradation. Hydroponically grown tomatoes responded to increased rates of $\mathrm{K}$ and $\mathrm{P}$ with increased lycopene (20\% to 30\%) (Dumas et al., 2003; Trudel and Ozbun, 1971). Fresh market tomatoes, watermelon, and red grapefruit had little or no increase in lycopene with increased soil $\mathrm{K}$ rates in field experiments (Fontes et al., 2000; Patil and Alva, 2002; Perkins-Veazie and Roberts, 2003). Applications of $P$ at high rates failed to increase lycopene levels in juice from processing tomatoes (Oke et al., 2005).

Lycopene production in response to water quality and amount depends on crop and germplasm. When watermelon plants were irrigated at full, three-fourths or one-half of evapotranspiration rates, fruit lycopene contents were not significantly different (Leskovar et al., 2004). Tomato response to water availability depended on type and cultivar with a decrease in lycopene found with decreased soil water in three cultivars, and an increase in lycopene seen in cherry or greenhouse-grown beefsteak types (Dumas et al., 2003). Using saline water (to $0.25 \%$ $\mathrm{NaCl} \mathrm{w} / \mathrm{v}$ ) increased lycopene content of tomatoes (De Pascale et al., 2001; Krauss et al., 2006). Use of other types of ions for salinity treatments (such as calcium or sulfate) has not been reported.

\section{Postharvest Storage Treatments}

The most common stimulators of lycopene synthesis in harvested fruit are storage temperature and ethylene. Generally, storage temperatures of 20 to $30{ }^{\circ} \mathrm{C}$ stimulate lycopene production, whereas temperatures of $5{ }^{\circ} \mathrm{C}$ or less reduce lycopene (Hobson, 1987; Soto-Zamora et al., 2005) (Table 4). Ethylene, a plant hormone, stimulates ripening, cell wall softening, and subsequent lycopene formation in tomatoes and bitter melon. Application of exogenous ethylene to watermelon caused cellular breakdown of placental tissue in immature and mature fruit and increased lycopene content by 10\% (Don Huber, University of Fla., personal communication). Compounds that block ethylene receptors such as carbon dioxide and 1methylcyclypropane (1-MCP) also block or slow ethylene-triggered lycopene formation, and their effects depend on stage of ripeness and temperature (Table 4) (Baldwin, 2004). Controlled and MA storage (low $\mathrm{O}_{2} /$ high $\mathrm{CO}_{2}$ at $20 \%, 40 \%$, or $60 \%$ ) blocked lycopene synthesis in fresh market tomatoes harvested at mature green, light pink, and turning stages (Buescher, 1979). In another study, CA storage $\left(3 \% \mathrm{O}_{2}\right.$ or $\left.20 \% \mathrm{CO}_{2}\right)$ for $150 \mathrm{~h}$ reduced lycopene and total carotenoid biosynthesis by $40 \%$ and prevented ethylene production in the long shelf-life tomato variety 'CF114' (Sozzi et al., 1999). Lycopene formation in mature green tomatoes was delayed for 6 to $18 \mathrm{~d}$ at 15 to $25^{\circ} \mathrm{C}$ after treatment with $0.25 \mu \mathrm{L} \mathrm{nL} \cdot \mathrm{L}^{-1} 1-\mathrm{MCP}$ (Mostofi et al., 2003). However, the 1-MCP treatment did not 
Table 1. Plant material sources of lycopene $(\mathrm{mg} / \mathrm{kg})$.

\begin{tabular}{|c|c|c|c|}
\hline \multicolumn{2}{|c|}{ Food } & \multirow{2}{*}{$\begin{array}{l}\text { Lycopene } \\
\text { content }\end{array}$} & \multirow[b]{2}{*}{ Reference } \\
\hline Fruits and Vegetables & Scientific Name & & \\
\hline \multicolumn{4}{|l|}{ Fresh Weight } \\
\hline Asparagus (cooked) & Asparagus officinalis & 0.30 & U.S. Department of Agriculture, 2005 \\
\hline Autumn olive & Elaeagnus umbellata & $150-540$ & Fordham et al., 2001 \\
\hline Carrots, orange & Daucus carota & 0.02 & U.S. Department of Agriculture, 2005 \\
\hline Ripe tomatoes & $\begin{array}{l}\text { Lycopersicon } \\
\text { esculentum }\end{array}$ & 25.73 & U.S. Department of Agriculture, 2005 \\
\hline Gac Fruit-aril & $\begin{array}{l}\text { Momordica } \\
\text { cochinchinesis }\end{array}$ & $348-1902$ & Aoki et al., 2002; Ishida et al., 2004 \\
\hline Grapefruit & Citrus paradisi & 14.19 & U.S. Department of Agriculture, 2005 \\
\hline Guavas & Psidium guajava & 52.04 & U.S. Department of Agriculture, 2005 \\
\hline Japanese persimmon & Diospyros kaki & $1.59-5.34$ & $\begin{array}{l}\text { de Ancos et al., 2000; } \\
\text { U.S. Department of Agriculture, } 2004\end{array}$ \\
\hline Pitanga & Eugenia uniflora & 73.00 & Rodriguez-Amaya, 1999 \\
\hline Red cabbage & $\begin{array}{l}\text { Brassica oleracea } \\
\quad \text { (Capitata Group) }\end{array}$ & 0.20 & U.S. Department of Agriculture, 2005 \\
\hline Red carrots & Daucus carota. & 61.00 & $\begin{array}{l}\text { Cavalcante and Rodriguez-Amaya, } \\
\text { 1992; Surles et al., } 2004\end{array}$ \\
\hline Red-fleshed papaya & Carica papaya & 19.41 & Rodriguez-Amaya, 1999 \\
\hline Red navel orange & Citrus sinensis & 3.90 & Lee, 2001 \\
\hline Sweet red peppers & Capsicum annuum & 3.08 & U.S. Department of Agriculture, 2005 \\
\hline Watermelon & Citrullus lanatus & 45.32 & U.S. Department of Agriculture, 2005 \\
\hline \multicolumn{4}{|l|}{ Dry Weight } \\
\hline Apricots & Prunus armeniaca, & $3.20-19.00$ & $\begin{array}{l}\text { deRigal et al., 2000; } \\
\text { Khachik et al., } 1991\end{array}$ \\
\hline Bitter melon-aril & Momordica charantia & 411.00 & Tran and Raymundo, 1999 \\
\hline Rose hips & Rosaceae canina & 21.82 & Hodisan et al., 1997 \\
\hline Swede & Brassica rapa & 0.50 & Burns et al., 2003 \\
\hline
\end{tabular}

Table 2. Processed food sources of lycopene ( $\mathrm{mg} / \mathrm{kg}$ and as $\mathrm{mg} / \mathrm{serving}$ ).

\begin{tabular}{|c|c|c|c|}
\hline \multirow[b]{2}{*}{ Food } & \multirow[b]{2}{*}{ Lycopene per kg (mg) } & \multicolumn{2}{|c|}{ Content } \\
\hline & & Per serving size & Common serving \\
\hline \multicolumn{4}{|l|}{ Processed Foods } \\
\hline Sauce from pizza & 328.90 & na & $\mathrm{Na}$ \\
\hline Tomato paste & 287.64 & 75.36 & 1 cup \\
\hline Prepared spaghetti sauce & 159.90 & 39.98 & 1 cup \\
\hline Canned tomato sauce & 151.52 & 37.12 & 1 cup \\
\hline Canned pizza sauce & 127.10 & na & $\mathrm{Na}$ \\
\hline Vegetable juice cocktail & 96.60 & 23.38 & 1 cup \\
\hline Tomato juice, canned & 90.37 & 21.96 & 1 cup \\
\hline Tomato soup & 54.60 & 13.32 & 1 cup \\
\hline \multicolumn{4}{|l|}{ Condiments and Spices } \\
\hline Catsup & 170.07 & 2.55 & 1 Tbsp. \\
\hline Salsa-ready to serve & 108.76 & 1.74 & 1 Tbsp. \\
\hline Barbecue sauce & 4.29 & 0.07 & 1 Tbsp. \\
\hline \multicolumn{4}{|l|}{ Salad Dressings } \\
\hline Thousand Island & 25.97 & 0.41 & 1 Tbsp. \\
\hline Russian & 6.27 & 0.097 & 1 Tbsp. \\
\hline French & 3.73 & 0.058 & 1 Tbsp. \\
\hline \multicolumn{4}{|l|}{ Spices } \\
\hline Cinnamon-ground & 0.29 & 0.0007 & $1 \mathrm{tsp}$. \\
\hline Chili powder & 0.21 & 0.0005 & $1 \mathrm{tsp}$. \\
\hline Black pepper & 0.06 & 0.0001 & 1 tsp. \\
\hline
\end{tabular}

Sources: Nguyen and Schwartz, 1998; USDA, 2005a.

affect final lycopene content compared with the control (Mostofi et al., 2003).

\section{Processing and Preservation}

Several processing systems, from minimal processing to heating, canning, drying, and extraction, have been studied relative to lycopene preservation. Fresh-cut plant materials generally show small amounts of carotenoid loss with little changes in lycopene isomerization. Fresh-cut watermelon held for $10 \mathrm{~d}$ at $2{ }^{\circ} \mathrm{C}$ or $5{ }^{\circ} \mathrm{C}$ lost $6 \%$ to $11 \%$ total lycopene (Perkins-Veazie and Collins, 2004), whereas no losses in lycopene were found in
Exposure of tissue to oxygen and formation of ice crystals may cause losses of total lycopene in frozen fruit. For instance, pureed watermelon had less ice crystal formation and lost less lycopene than diced fruit held for a year at $-20{ }^{\circ} \mathrm{C}$, and only $5 \%$ to $10 \%$ of lycopene was lost in watermelon held at $-80{ }^{\circ} \mathrm{C}$ (Fish and Davis, 2003). Frozen cubed tomatoes also lost less lycopene when held at lower temperatures (Table 4) (Lisiewska and Kmiecik, 2000). Even the type of storage container can affect losses, with red grapefruit concentrates stored in plastic containers having less lycopene loss than that stored in metal cans (Lee and Coates, 2002).

Heat processing can cause lycopene loss and isomerization, depending on processing time and temperature. Canned tomato products are processed using hot break (heating to $95{ }^{\circ} \mathrm{C}$ ) or cold break (heating to $65{ }^{\circ} \mathrm{C}$ ) methods. In the hot break method, the pectin enzymes are destroyed from the heat, whereas in cold break, pectin enzymes are still active resulting in pectin breakdown. The cold break method is used for juices and soups because it reduces viscosity and results in improved color and flavor compared with the hot break method (Anthon and Barrett, 2003). Tomatoes processed under conventional industrial heat or hot break, cold break, or super cold break processing methods had a $9 \%$ to $28 \%$ loss in total lycopene (Nguyen and Schwartz, 1998; Re et al., 2002; Takeoka et al., 2001).

Combined heat and pressure can have a detrimental effect on carotenoid stability. Persimmon fruit purees treated with $300 \mathrm{MPa}$ of pressure for $15 \mathrm{~min}$ at $25{ }^{\circ} \mathrm{C}$ had no decrease in lycopene or total carotenoids compared with 50,150, and $400 \mathrm{MPa}$ highpressure sterilization processing treatments at $25{ }^{\circ} \mathrm{C}$ (de Ancos et al., 2000).

A higher amount of surface area in a product exposed to drying, as well as drying method, induces lycopene loss and negatively affects stability. Tomato halves, which have far less surface area than pulp or processing byproducts (peel, seed, etc), retained lycopene when dried at $80^{\circ} \mathrm{C}$, but lost $12 \%$ lycopene when dried at $110^{\circ} \mathrm{C}$ (Zanoni et al., 1999). Air, vacuum, and osmoticvacuum drying are the least damaging to tomato pulp or processing waste lycopene ( $2 \%$ to $4 \%$ initial loss), and spray drying is the most damaging (Shi et al., 1999). In spray-dried tomato pulp, increasing air temperatures and flow rates increased initial lycopene loss from $8 \%$ to $21 \%$ (Goula and Adamopoulos, 2004).

Once dried, lycopene is very unstable, with losses as high as $60 \%$ to $97 \%$ (Giovanelli and Paradiso, 2002). The rate of degradation is increased by exposure to high temperatures, light and oxygen, and low moisture content resulting in isomerization from trans- to cis- forms and from autooxidation of trans-lycopene (Giovanelli and Paradiso, 2002). In early studies on dried tomato powders, researchers found significant lycopene loss from samples stored under air compared with those that were stored 
Table 3. Production practices and environmental effects during drying season on lycopene content.

\begin{tabular}{|c|c|c|c|c|}
\hline Variable & Range & Commodity & Result & Reference \\
\hline \multirow[t]{3}{*}{$\begin{array}{l}\text { Air } \\
\text { temperature }\end{array}$} & $>32{ }^{\circ} \mathrm{C}$ & Tomato & $\begin{array}{l}\text { Decreased lycopene, } \\
\text { increased beta-carotene }\end{array}$ & $\begin{array}{l}\text { Goodwin and Jamikorn, } \\
\text { 1952; Tomes, 1963; } \\
\text { Vogele, } 1937\end{array}$ \\
\hline & $20-37^{\circ} \mathrm{C}$ & Watermelon & No change in lycopene & Vogele, 1937 \\
\hline & $4-21^{\circ} \mathrm{C}$ & Grapefruit & $\begin{array}{l}\text { Reduced lycopene } \\
\text { content }\end{array}$ & $\begin{array}{l}\text { Meredith and Young, } \\
\text { 1971; Purcell et al., } 1968\end{array}$ \\
\hline \multirow[t]{2}{*}{ Fertility } & Increased $\mathrm{K}$ & Tomato & $\begin{array}{l}\text { Increased lycopene in } \\
\text { controlled } \\
\text { environment, } \\
\text { no change in field }\end{array}$ & $\begin{array}{l}\text { Fontes et al., 2000; } \\
\text { Trudel and Ozbun, } \\
1971\end{array}$ \\
\hline & Increased $\mathrm{P}$ & Tomato & $\begin{array}{l}\text { Increased lycopene in } \\
\text { controlled } \\
\text { environment, no } \\
\text { change in field }\end{array}$ & $\begin{array}{l}\text { Dumas, 2003; } \\
\text { Oke et al., } 2005\end{array}$ \\
\hline \multirow[t]{2}{*}{ Irrigation } & $\begin{array}{l}40 \% \text { to } 70 \% \text { soil } \\
\text { water depletion }\end{array}$ & Tomato & $\begin{array}{l}\text { Increased lycopene in } \\
\text { cherry types reduced in } \\
\text { slicing types. }\end{array}$ & Dumas, 2003 \\
\hline & ET 0.5 to 1.0 & Watermelon & No change in lycopene & Leskovar et al., 2004 \\
\hline
\end{tabular}

ET $=$ evapotranspiration.

Table 4. Storage practices and their effects on lycopene content.

\begin{tabular}{|c|c|c|c|c|}
\hline Variable & Range & Crop & Result & Reference \\
\hline \multirow[t]{5}{*}{ Temperature } & $20-30{ }^{\circ} \mathrm{C}$ & Tomato & $\begin{array}{l}\text { Accelerates lycopene } \\
\text { accumulation at all } \\
\text { color stages }\end{array}$ & Hobson, 1987 \\
\hline & $<5^{\circ} \mathrm{C}$ & Tomato & $\begin{array}{l}\text { Reduces lycopene } \\
\text { by } 50 \% \text { in mature } \\
\text { green, } 10 \% \text { in red }\end{array}$ & Hall, 1961 \\
\hline & $>20{ }^{\circ} \mathrm{C}$ & Watermelon & $\begin{array}{l}\text { Increases lycopene } \\
\text { content by } 20 \% \text { in ripe }\end{array}$ & $\begin{array}{l}\text { Perkins-Veazie et al., } \\
\quad 2005\end{array}$ \\
\hline & $<5^{\circ} \mathrm{C}$ & Watermelon & $\begin{array}{l}\text { Reduces lycopene } \\
\text { content in ripe } \\
\text { fruit by } 10 \%\end{array}$ & $\begin{array}{l}\text { Perkins-Veazie et al., } \\
\quad 2005\end{array}$ \\
\hline & $>35^{\circ} \mathrm{C}$ & Bitter melon & $\begin{array}{l}\text { Decreased lycopene } \\
\text { in arils }\end{array}$ & $\begin{array}{l}\text { Tran and Ramundo, } \\
1999\end{array}$ \\
\hline \multirow[t]{3}{*}{ Atmosphere } & Oxygen $3 \%$ & Tomato & $\begin{array}{l}\text { Reduced lycopene } \\
\text { content }\end{array}$ & Sozzi et al., 1999 \\
\hline & $\mathrm{CO}_{2} 20 \%$ & Tomato & $\begin{array}{l}\text { Reduced lycopene } \\
\text { content }\end{array}$ & Sozzi et al., 1999 \\
\hline & $\mathrm{CO}_{2} 5 \%$ to $10 \%$ & Tomato & $\begin{array}{l}\text { Delayed color } \\
\text { development }\end{array}$ & Buescher, 1979 \\
\hline \multirow[t]{2}{*}{ 1-MCP } & $250 \mu \mathrm{l} / \mathrm{L}$ & Tomato & $\begin{array}{l}\text { Delayed lycopene } \\
\text { accumulation in } \\
\text { mature green }\end{array}$ & Mostofi et al., 2003 \\
\hline & $70-110 \mu \mathrm{l} / \mathrm{L}$ & Cherry Tomato & $\begin{array}{l}\text { Delayed lycopene } \\
\text { accumulation and } \\
\text { color development }\end{array}$ & Opiyo and Ying, 2005 \\
\hline
\end{tabular}

$1-\mathrm{MCP}=1-$ methyl-cyclopropane.

under nitrogen or vacuum packed (Miers et al., 1958; Wong and Bohart, 1957). Freezedried and oven-dried tomato pulp had similar initial lycopene losses, but oven-dried pulp was more stable after 4 months of storage at ambient temperature, light, and atmosphere in closed containers (Sharma and Le Maguer, 1996). In tomato powders, lycopene is reported to isomerize from trans to $\mathrm{cis}$ forms as much as $30 \%$ to $60 \%$ after 6 weeks of storage, with rate of loss dependent on temperature and light conditions under storage (Anguelova and Warthesen, 2000). Tomato powders stored at $45{ }^{\circ} \mathrm{C}$ for 6 weeks had the most lycopene loss and isomerization (60\%) (Anguelova and Warthesen, 2000). Cold also negatively affected stability, with a $30 \%$ lycopene loss in powders stored at $-10,2$, or $6{ }^{\circ} \mathrm{C}$ in the dark compared with those stored at 20 or $25{ }^{\circ} \mathrm{C}$ under light or dark odors" possibly resulting from the autooxidation of lycopene into smaller ketone and aldehyde compounds (Anguelova and Warthesen, 2000) and darkening of red powders to brick-red color resulting from an increase in 5-hydroxymethyl-2-furfural (HMF) compounds, especially when powders are airdried, spray-dried, or stored above room temperatures (Anguelova and Warthesen, 2000; Giovanelli and Paradiso, 2002; Zanoni et al., 1999).

\section{Extraction Products}

Extraction of lycopene from its plant matrix for use as natural food colorants or supplements is of considerable commercial interest, currently valued at $\$ 34$ million in the United States (Frost and Sullivan Company, 2003). Although lycopene extraction was studied extensively in the 1950 s, more successful methods of extraction and recovery have been developed. Considerable lycopene loss can happen during processing and storage, and depends on surface area of the material, temperature, atmosphere, exposure time, and light during processing and storage (Rodriguez-Amaya, 2001). In addition to concerns about recovery and stability, isomerization of lycopene from trans to cis forms can occur.

Supercritical fluid extraction has been explored more recently as a method for lycopene extraction from byproducts (i.e., skin and seeds) of tomato processing (Rozzi et al., 2002). Pressure, temperature, extraction modifiers and solvents affect recovery, with $41 \%$ to $61 \%$ lycopene recovered from tomatoes (Baysal et al., 2000; Gomez-Prieto et al., 2003; Rozzi et al., 2002) (Table 5). Usually, $\mathrm{CO}_{2}$ is used as the extraction solvent and ethanol is used as the modifier. Generally, lycopene recovery increases when pressure or extraction temperatures increase, but lycopene isomerization may occur. Lycopene extraction or semipurification efficiency has been studied most extensively with tomato. Methodologies may need to be altered with other lycopene-containing plant materials, and the degree of isomerization, as well as lycopene loss, need to be documented in all studies.

Anguelova and Warthesen, 2000; Lovric et al., 1970).

Critical moisture level relative to surface area also affects lycopene stability. Critical moisture levels of $20 \%$ to $40 \%$ and temperatures lower than $18{ }^{\circ} \mathrm{C}$ were necessary to prevent lycopene losses in dried tomato halves stored under vacuum (Zanoni et al., 2000). Conversely, tomato pulp air-dried to 9\% moisture was more stable than pulp at $23 \%$ moisture after storage at 4,30 , and $37^{\circ} \mathrm{C}$ (Giovanelli and Paradiso, 2002). Researchers concluded that some water was necessary to protect against oxidative changes initiated by metal ions and hydroperoxide molecules, but too much could enhance the movement of oxidative substrates, promoting lycopene loss (Giovanelli and Paradiso, 2002). Oxidative changes reported during storage of dried tomato are the development of "grassy off-

\section{Lycopene Absorption in Humans}

Studies on lycopene related to human health is recent, unlike beta-carotene, a provitamin A carotenoid that was heavily researched. An estimated $50 \%$ of daily lycopene intake is from heat processed tomato products such as tomato sauce and paste that is more readily absorbed from the gastrointestinal tract than lycopene from raw tomatoes (Bohm and Bitsch, 1999). Lycopene from other foods such as watermelon is readily absorbed by humans without heat processing, indicating that the plant matrix is important for digestion and absorption (Edwards et al., 2003). Lower blood levels of lycopene were found in subjects ingesting muffins prepared with red carrots than from 
Table 5. Summary of treatments resulting in greatest lycopene recovery using supercritical fluid extraction methods.

\begin{tabular}{|c|c|c|c|c|c|c|}
\hline Material used & Modifier & Temperature & Pressure & Flow Rate & $\%$ Recovery & Reference \\
\hline $\begin{array}{l}\text { Tomato paste } \\
\text { waste }\end{array}$ & $\begin{array}{l}\mathrm{CO}_{2} / 5 \% \\
\text { Ethanol }\end{array}$ & $55^{\circ} \mathrm{C}$ & $30 \mathrm{Mpa}$ & $4 \mathrm{~kg} / \mathrm{h}$ & 54 & $\begin{array}{l}\text { Baysal et al., } \\
2000\end{array}$ \\
\hline $\begin{array}{l}\text { Tomato seeds } \\
\text { and skin }\end{array}$ & $\mathrm{CO}_{2}$ & $86{ }^{\circ} \mathrm{C}$ & $34.5 \mathrm{Mpa}$ & $2.5 \mathrm{ml} / \mathrm{min}$ & 61 & $\begin{array}{l}\text { Rozzi et al., } \\
2002\end{array}$ \\
\hline $\begin{array}{l}\text { Tomato skin } \\
\text { and pulp }\end{array}$ & $\mathrm{CO}_{2}$ & $40{ }^{\circ} \mathrm{C}$ & $28.1 \mathrm{Mpa}$ & $4 \mathrm{ml} / \mathrm{min}$ & 42 & $\begin{array}{l}\text { Gomez et al., } \\
2003\end{array}$ \\
\hline $\begin{array}{l}\text { Tomato seeds } \\
\text { and skin }\end{array}$ & $\mathrm{CO}_{2}$ & $80{ }^{\circ} \mathrm{C}$ & $27.5 \mathrm{Mpa} 5$ & $00 \mathrm{~cm}^{2} / \mathrm{min}$ & 64 & $\begin{array}{l}\text { Cadoni et al., } \\
2000\end{array}$ \\
\hline $\begin{array}{l}\text { Tomato seeds } \\
\text { and skin }\end{array}$ & $\mathrm{CO}_{2}$ & $80^{\circ} \mathrm{C}$ & $30.0 \mathrm{Mpa}$ & $0.792 \mathrm{~kg} / \mathrm{h}$ & 80 & $\begin{array}{l}\text { Sabio et al., } \\
2003\end{array}$ \\
\hline $\begin{array}{l}\text { Sun-dried } \\
\text { tomato }\end{array}$ & $\begin{array}{l}\mathrm{CO}_{2} / 10 \% \\
\text { Hazelnut oil }\end{array}$ & $66{ }^{\circ} \mathrm{C}$ & $45.0 \mathrm{Mpa}$ & $20 \mathrm{~kg} / \mathrm{hr}$ & 60 & $\begin{array}{l}\text { Vasapollo et al., } \\
2004\end{array}$ \\
\hline
\end{tabular}

those prepared with tomato paste, indicating an interference in absorption from dietary fiber (Horvitz et al., 2004). Heat processing and homogenization is speculated to break protein-carotenoid complexes to release lycopene from cell wall linkages and improve uptake (Bohm and Bitsch, 1999; Gartner et al., 1997; het Hof et al., 2000; Shi and Le Maguer, 2000). Other researchers have reported that lycopene is preferentially taken up from a supplement form compared with tomato juice, again probably a plant matrix effect (Paetau et al., 1999). Because lycopene is a fat-soluble compound, fat ingested with lycopene improves its uptake in humans (Rao, 2004; Unlu et al., 2005).

Lycopene is stored in various organs of the body with greatest stores in adrenal glands, liver, adipose tissue and prostate, colon, skin, cervix, breast, and lung (Erdman et al., 1993; Khachik et al., 2002a, 2002b). In humans, lycopene is isomerized during digestion from trans to cis forms and blood concentrations vary from 0.6 to $1.9 \mathrm{nmol} / \mathrm{ml}$ (Khachik et al., 2002a). The importance of isomer forms on the mechanisms of health benefits to human is unknown, but cis isomers seem to exhibit stronger antioxidant activity in vitro than trans forms and may be preferentially absorbed (Erdman, 2005; Stahl and Sies, 1992; Stahl et al., 1992). Because of the potential health contributions of lycopene, most combination vitamin and mineral supplements contain 0.3 to $2.0 \mathrm{mg}$ of synthesized lycopene, although the U.S. Food and Drug Administration has not determined upper or lower intake levels for supplemental lycopene.

\section{Epidemiologic Studies}

Epidemiologic studies are defined as "studies on the distribution and determinants of disease, injury or dysfunction in human populations" (Portney and Watkins, 2000). Most epidemiologic studies on lycopene are classified as observational studies and are categorized as case-control or cohort studies. In case-control studies, case subjects are screened for the disorder being studied and controls are selected as the comparison group without the disorder. Subjects are then interviewed for history or exposure elements or in clinical settings and their medical history is reviewed for specific risk factors. Subjects are often matched by age, gender, race, or ethnic background to eliminate confounding variables in the analysis (Portney and Watkins, 2000). In cohort studies, a group of individuals are followed over a length of time to determine if they develop disease conditions and what factors (exposures) influenced the disease condition (Portney and Watkins, 2000). Examples of ongoing cohort studies are the Nurses' Health Study $(80,000$ cohorts over 28 years) and the Health Professionals Study $(47,909$ cohorts over 18 years $)$ (Giovannucci, 1999; Sesso et al., 2003). There have been numerous epidemiologic studies, both cohort and case-control,that have correlated fewer occurrences of cancers of the breast, cervix, lung, stomach, bladder, pancreas, ovary, and prostate with diets high in fruits and vegetables (Buiatti et al., 1996; Giovannucci et al., 1995; Grievink et al., 2000; Ronco et al., 1999; Sato et al., 2002; Steinmetz et al., 1993). Of the vegetables, tomato products or lycopene are associated with reduced risk for cancers of the lung, breast, stomach, and prostate, with the strongest evidence linking reduction in prostate cancers in the men's Health Professionals Study with lycopene-containing foods (De Stefani et al., 2000; Giovannucci, 2002; Grievink et al., 2000; Levi et al., 2001). Other epidemiologic studies have reported reduced cardiovascular disease with lycopene-rich diets (Gianetti et al., 2002; Rissanen et al., 2001; Sesso et al., 2003, 2004).

\section{Cancer Cell-Line Studies}

In human research, in vitro studies provide valuable information on the effectiveness a compound has in mitigating growth of cancer cell lines and dosage levels of compounds can be explored before using in intervention studies. In several cancer cellline studies, lycopene reduced cancer cell growth and induced apoptosis (cell death) in malignant leukemia cell, endometrial, mammary, lung cancer, breast cancer, and prostate cancer cells (Amir et al., 1999; Kotake-Nara et al., 2001; Levy et al., 1995; Muller et al., 2002). A synergistic effect (more reduction in cell proliferation) was found with lycopene and low concentrations of 1,25-dihydroxyvitamin $\mathrm{D}_{3}$ (vitamin D) (Amir et al., 1999). Other carotenoids commonly found in plant foods that demonstrate synergistic apoptosis activity when used with lycopene include phytofluene, zeta-carotene, neoxanthin, and fucoxanthin (Kotake-Nara et al., 2001). One chemopreventive action of lycopene is upregulation of connexin 43, a gap-junctional protein that is involved in cell signaling (Bertram, 1999). When connexin 43 is upregulated, there is a transfer of nutrients or signaling molecules between connected cells, resulting in the growth inhibition of chemically transformed cells (Bertram, 1999).

\section{Antioxidant Studies}

One of the current theories in disease promotion is the prooxidant/antioxidant theory (Meydani et al., 1998). Prooxidants such as superoxide free radicals are produced as byproducts of normal respiration in the mitochondria of the cell (Fukagawa, 1999). It is thought that $\approx 1 \%$ to $3 \%$ of the oxygen taken into the body is converted into superoxide species or other reactive oxygen species (Fang et al., 2002). Unless halted, the reactive oxygen radicals can react with DNA bases and proteins, causing mutations. Radicals can also react with unsaturated fatty acids in the cell membrane to form lipid peroxy radicals, which are highly reactive and can cause a propagating chain of cellular damage (Fang et al., 2002; Fukagawa, 1999). In most cases, the human body produces enzymes that slow or halt the action of these reactive oxygen species (Wei and Lee, 2002). However, in disease states or during aging, the body's enzymes are not as efficient in quenching the activity of these molecules with the imbalance in repair mechanisms thought to accelerate the initiation of disease states (Wei and Lee, 2002). Plant-based phytochemicals are thought to act as antioxidants by scavenging or halting the action of superoxide or peroxy radicals.

Numerous in vitro studies have been conducted to determine the effectiveness of lycopene as an antioxidant. Carotenoids halt free radical activity by physical and chemical quenching activities in electron transfer, hydrogen abstraction, and binding with radical species (Young and Lowe, 2001). Peroxynitrite is produced from nitric oxide and superoxide and has strong oxidizing properties that can react with protein-lipid complexes. Lycopene, beta-carotene, alphacarotene, lutein, zeaxanthin, and beta-cryptoxanthin were reported to be efficient agents in preventing peroxynitrite damage (Panasenko et al., 2000). Carotenoid oxygen-quenching activity at the cellular level is related to the number of conjugated double bonds present. Lycopene contains two additional nonconjugated double bonds compared with other carotenoids. This bond structure confers twice as much singlet oxygen quenching ability compared with beta-carotene in human plasma (Di Mascio et al., 1989). Lycopene also protects against lipid peroxidation. Low-density lipoproteins in human blood are comprised of unsaturated fatty acids and can be oxidized by free radicals and peroxidizing agents. Lycopene 


\begin{tabular}{|c|c|c|c|c|c|}
\hline Source of lycopene & $\begin{array}{c}\text { Amount of } \\
\text { lycopene (mg) }\end{array}$ & $\begin{array}{l}\text { Number of subjects, } \\
\text { gender, age, other } \\
\text { condition }\end{array}$ & Variables measured & Conclusions & Reference \\
\hline $\begin{array}{l}\text { Whole tomatoes, } \\
\text { tomato juice, } \\
\text { tomato } \\
\text { oleoresin }\end{array}$ & 5 & $20+$ & $\begin{array}{l}\text { Lycopene absorption } \\
\text { and antioxidant } \\
\text { tests (TEAC, } \\
\text { TRAP) in plasma. }\end{array}$ & $\begin{array}{l}\text { Better lycopene } \\
\text { absorption from } \\
\text { tomato juice and } \\
\text { tomato oleoresin } \\
\text { than from fresh } \\
\text { whole tomatoes. } \\
\text { No differences in } \\
\text { antioxidant } \\
\text { response. }\end{array}$ & $\begin{array}{l}\text { Bohm and } \\
\text { Bitsch, } 1999\end{array}$ \\
\hline Tomato puree & 7 & 11 & $\begin{array}{l}\text { Lycopene absorption } \\
\text { and antioxidant } \\
\text { tests (TRAP) using } \\
\text { plasma. }\end{array}$ & $\begin{array}{l}\text { Lycopene absorption. } \\
\text { No differences in } \\
\text { antioxidant } \\
\text { response. }\end{array}$ & Pellegrini et al., 2000 \\
\hline Tomato juice & 40 & 25 & $\begin{array}{l}\text { TBARS, FRAP } \\
\text { Glutathione } \\
\text { enzymes. }\end{array}$ & $\begin{array}{l}\text { Lycopene reduced } \\
\text { lipid peroxidation } \\
\text { (TBARS). No } \\
\text { differences in other } \\
\text { antioxidant tests. }\end{array}$ & Bub et al., 2000 \\
\hline Tomato juice & 15,45 & 31 & $\begin{array}{l}\text { LDL oxidation in } \\
\text { plasma. }\end{array}$ & $\begin{array}{l}\text { Lycopene reduced low } \\
\text { density lipoprotein } \\
\text { oxidation. }\end{array}$ & Maryuma et al., 2001 \\
\hline Synthetic supplement & 15 & 175 & $\begin{array}{l}\text { Glutathione (GSH and } \\
\text { GSGG) copper and } \\
\text { zinc superoxide } \\
\text { dismutase, and } \\
\text { selenium } \\
\text { glutathione } \\
\text { peroxidase in } \\
\text { plasma. }\end{array}$ & $\begin{array}{l}\text { No change in any } \\
\text { variables. }\end{array}$ & Hininger et al., 2001 \\
\hline $\begin{array}{l}\text { Tomato juice, } \\
\text { watermelon juice }\end{array}$ & 20,40 & 23 & $\begin{array}{l}\text { Lycopene absorption, } \\
\text { FRAP, cholesterol, } \\
\text { glutathione } \\
\text { peroxidase in } \\
\text { plasma. }\end{array}$ & $\begin{array}{l}\text { Similar lycopene } \\
\text { absorption from } \\
\text { tomato and } \\
\text { watermelon juice, } \\
\text { no heat processing } \\
\text { in watermelon. No } \\
\text { differences in } \\
\text { antioxidant or } \\
\text { cholesterol } \\
\text { response. }\end{array}$ & $\begin{array}{l}\text { Collins et al., 2004; } \\
\text { Edwards et al., } 2003\end{array}$ \\
\hline $\begin{array}{l}\text { Lycopene-15 mg } \\
\text { supplement }\end{array}$ & 15 & 8 & $\begin{array}{l}\text { DNA oxidative } \\
\text { damage (Comet } \\
\text { assay). }\end{array}$ & $\begin{array}{l}\text { Lycopene reduced } \\
\text { DNA damage. }\end{array}$ & $\begin{array}{r}\text { Torbergsen and } \\
\text { Collins, } 2000\end{array}$ \\
\hline Tomato juice & 40 & 23 & $\begin{array}{l}\text { DNA oxidative } \\
\text { damage (Comet } \\
\text { assay). }\end{array}$ & $\begin{array}{l}\text { Lycopene reduced } \\
\text { DNA strand breaks. }\end{array}$ & Pool-Zobel et al., 1997 \\
\hline $\begin{array}{l}\text { Synthetic } \\
\text { supplement }\end{array}$ & 15 & $\begin{array}{l}26 \text { men with } \\
\text { prostate cancer }\end{array}$ & IGF-1, PSA in blood. & $\begin{array}{l}\text { Lycopene reduced } \\
\text { PSA levels }(14 \%) \text { no } \\
\text { effect on IGF-1. }\end{array}$ & Kucuk et al., 2001 \\
\hline Tomato sauce & 30 & $\begin{array}{l}32 \text { men with } \\
\text { prostate cancer }\end{array}$ & $\begin{array}{l}\text { Blood serum and } \\
\text { prostate lycopene } \\
\text { levels PSA, DNA } \\
\text { oxidative damage } \\
\text { Modulation of } \\
\text { cancer. }\end{array}$ & $\begin{array}{l}\text { Lycopene increased in } \\
\text { serum and prostate } \\
\text { Reduced PSA } \\
\text { levels }(17 \%), \text { DNA } \\
\text { damage }(21 \%) \text {, and } \\
\text { tumor size. }\end{array}$ & $\begin{array}{r}\text { van Breeman } \\
\text { et al., } 2002\end{array}$ \\
\hline
\end{tabular}

TEAC $=$ Trolox equivalent antioxidant capacity; TRAP $=$ radical trapping antioxidant parameter; TBARS $=$ thiobarbituric acid reactive substances; DNA $=$ deoxyribonucleic acid; FRAP = ferric-reducing ability of plasma; IGF-1 = insulin growth factor-1; PSA = prostate-specific antigen; LDL = low-density lipoproteins.

is primarily attached to low-density lipoproteins in plasma and is thought to confer protection against lipid peroxidation and foam cell production, both of which are implicated in the initiation of atherosclerosis (Arab and Steck, 2000; Gianetti et al., 2002). In one in vitro study, lycopene reduced lipid peroxidation of cells exposed to a peroxidizing agent (ferric nitrilotriacetate) (Matos et al., 2000) with a greater reduction in lipid peroxidation when lycopene was combined with lutein (Stahl et al., 1998).
Three tests are commonly used to quantify antioxidant content: Trolox equivalent antioxidant capacity (TEAC), the radical trapping antioxidant parameter (TRAP) assay, and the ferric-reducing ability of plasma (FRAP). These assays are rapid, relatively easy methods for measuring the ability of antioxidant compounds to scavenge free radicals in blood, purified compounds, or plant extracts (Bohm et al., 2002; Bub et al., 2000). The TEAC test measures the total antioxidant capacity of a compound against a standard antioxidant, trolox, a water-soluble vitamin $\mathrm{E}$ analog (Djuric and Powell, 2001). TRAP measures the rate of thermally induced peroxidation of an azo-compound (Pellegrini et al., 2000). The FRAP assay measures an oxidation/reduction reaction by measuring the reduction of ferric-triyridltriazine to its ferrous form when combined with an antioxidant (Benzie and Strain, 1996).

In one in vitro antioxidant study, purified lycopene and its isomers were compared against beta-carotene, alpha-carotene, and zeaxanthin for (TEAC) activity. Lycopene in cis forms exhibited greater antioxidant 
activity compared with all trans forms, whereas all trans lycopene had greater TEAC activity than trans beta-carotene (Bohm et al., 2002). Additionally, antioxidant activities vary among foods that contain lycopene. In one study, researchers found higher antioxidant activity in heat-processed tomatoes compared with fresh tomatoes, presumably because processing improved the extraction and activity of antioxidant compounds (Dewanto et al., 2002). Antioxidant activities can vary between aqueous and organic extracts from the same food, indicating that other compounds, i.e., vitamin E, and watersoluble vitamin $\mathrm{C}$ and polyphenols, also express antioxidant activity and contribute to the whole food antioxidant profile (Djuric and Powell, 2001; Takeoka et al., 2001).

\section{Human Intervention Studies}

Currently, no long-term intervention studies have been conducted with lycopene because the effectiveness, safety, and dosage levels of lycopene on human health have not been established. Short-term studies have been conducted mostly with lycopene or tomato products, with varying results depending on lycopene dosage levels and type of antioxidant tests used (Table 6). The general findings are that 1) lycopene from processed tomato products such as juice or oleoresin is better absorbed than that of fresh tomato; 2) a minimum dosage of $4 \mathrm{mg}$ lycopene daily is needed to increase plasma levels of lycopene and to see reduced DNA damage or reduced low-density lipoprotein (LDL) oxidation; and 3) lycopene may effectively reduce prostate-specific antigen (PSA) levels and prostate tumor size with 8 to $30 \mathrm{mg}$ lycopene daily as a supplement or processed tomato source.

Three short-term lycopene intervention trials have been conducted with men with confirmed prostate cancer or with premaglignant prostate neoplasia (HGPIN). In the first prostate cancer study, 26 men with confirmed prostate cancer were supplemented with either $15 \mathrm{mg}$ purified lycopene or a placebo for 3 weeks before prostatectomy (removal of prostate) (Kucuk et al., 2001). Prostatespecific antigen levels (biomarker of prostate dysfunction) declined by $18 \%$ in lycopene treated subjects compared with unsupplemented men ( $14 \%$ increase) (Kucuk et al., 2001). In a larger research project funded by the National Cancer Institute, 32 men with prostate cancer were supplemented with 30 $\mathrm{mg}$ lycopene from tomato sauce for 3 weeks (van Breemen et al., 2002). Serum and prostate tissue lycopene levels increased threefold over initial levels, serum PSA levels decreased by $17.5 \%$, and cancer cells were modulated (Bowen et al., 2002). In a smaller dosage study, 40 patients with HGPIN were split into two groups; one half were given $8 \mathrm{mg}$ lycopene per day and the other group was not treated. Subjects were followed for 1 year and then evaluated for PSA levels and prostate malignancy. The treated groups had significantly reduced
PSA levels and number of prostate malignancies (Mohanty et al., 2005).

\section{Summary}

More than 245 epidemiologic studies have found that diets rich in fruits and vegetables can protect against cancer, stroke, and cardiovascular disease (Block et al., 1992; Joshipura et al., 1999, 2001; Steinmetz and Potter, 1996; Strandhagen et al., 2000). Because of these findings, the U.S. Department of Agriculture (2005b) changed the new dietary guidelines for healthy Americans to include five to 13 servings of fruits and vegetables per day, depending on caloric intake. Lycopene is one of many phytochemicals in fruit and vegetables that may act to protect against many of these diseases.

Because upper and lower intake levels have not been established for lycopene, most medical and nutrition experts agree that lycopene from a natural food state is preferable to supplements (Liu, 2003; Miller et al., 2002). Some researchers recommend intakes of $6 \mathrm{mg} /$ day of lycopene from food for health benefits (Porrini and Riso, 2005). Several commonly available fruits and vegetables are good sources of lycopene and are also good sources of other phytochemicals, including vitamin $\mathrm{C}$, vitamin $\mathrm{E}$, other carotenoids, dietary fiber, minerals, and phenolic compounds. Challenges exist for plant breeders to enhance lycopene levels in plant materials without altering quality, yield, shelf life, or other phytochemicals, and for food processors to maintain lycopene levels in plant materials without sacrificing initial carotenoid levels.

Phytochemicals may have independent or synergistic modes of action to protect cells against free radical damage. They may also affect cancer promotion/progression and halt inflammatory responses (Liu, 2003). More research is needed to determine if compounds in plant materials, especially carotenoids, can cause synergistic activities in vivo and to determine modes of action. Well-designed studies that are longer in duration that compare both lycopene and tomatoes/watermelon together will help clarify the areas of research that are conflicting.

Another new emerging area of research that may explain the health benefits of lycopene is nutrigenomics, described as a diet tailored for your genetics. It is known that some genetic polymorphisms in humans affect their metabolism of certain foods; common examples include lactose intolerance and alcohol dehydrogenase deficiency (German, 2005; Peregrin, 2001). Diseases linked to dietary patterns include cardiovascular disease, diabetes, and some cancers (Ommen and Stierum, 2002). Numerous genetic polymorphisms have been recently identified that influence heart disease risk (German, 2005). Preliminary data indicate that prostate cancer risk may be increased in a subset of individuals with a genetic variant who have a low intake of lycopene (Kristal and Schenk, 2005). Research in this area with lycopene is sketchy, but in an animal model of prostate cancer, androgen target genes and inflammatory signaling genes were upregulated with the cancer, whereas supplementation with tomato sauce downregulated gene expression (Stacewicz-Sapuntzakis and Bowen, 2005). Lycopene seemed to modulate the genes involved in prostate health. As new findings are made in this field, opportunities will arise for plant scientists, food technologists, nutritionists, and medical researchers to work together to create "tailored foods" for individuals or subgroups to help combat the plethora of diet-related diseases that affects the population.

\section{Literature Cited}

Adergoroye, A.S. and P.A. Jolliffe. 1987. Some inhibitory effects of radiation stress on tomato fruit ripening. J. Sci. Food Agr. 39:297302 .

Alba, R., M.M. Cordonnier-Pratt, and L.H. Pratt. 2000. Fruit-localized phytochromes regulate lycopene accumulation independently of ethylene production in tomato. Plant Physiol. 123:363-370.

Amir, H., M. Karas, J. Giat, M. Danilenko, R. Levy, T. Yermiahu, J. Levy, and Y. Sharoni. 1999. Lycopene and 1,25-dihydroxyvitamin D3 cooperate in the inhibition of cell cycle progression and induction of differentiation in HL-60 leukemic cells. Nutr. Cancer 33: 105-112.

Anguelova, T. and J. Warthesen. 2000. Lycopene stability in tomato powders. J. Food Sci. 65:6770.

Anthon, G.E. and D.M. Barrett. 2003. Thermal inactivation of lipoxygenase and hydroperoxytrienoic acid lycase in tomatoes. Food Chem. $80: 1-5$.

Aoki, H., N.T. Kieu, N. Kuze, K. Tomisaka, and N. Van Chuyen. 2002. Carotenoid pigments in GAC fruit (Momordica cochinchinensis SPRENG). Biosci. Biotechnol. Biochem. 66:2479-2482.

Arab, L. and S. Steck. 2000. Lycopene and cardiovascular disease. Amer. J. Clin. Nutr. 71: 1691S-1695S.

Arias, R., T.C. Lee, D. Specca, and H. Jones. 2000. Quality comparison of hydroponic tomatoes (Lycopersicon esculentum) ripened on and off vine. J. Food Sci. 65:545-548.

Baldwin, E.A. 2004. Ethylene and postharvest commodities. HortScience 39:1538-1540.

Baysal, T., S. Ersus, and D.A. Starmans. 2000. Supercritical $\mathrm{CO}(2)$ extraction of beta-carotene and lycopene from tomato paste waste. J. Agr. Food Chem. 48:5507-5511.

Benzie, I.F. and J.J. Strain. 1996. The ferric reducing ability of plasma (FRAP) as a measure of 'antioxidant power': The FRAP assay. Anal. Biochem. 239:70-76.

Bertram, J.S. 1999. Carotenoids and gene regulation. Nutr. Rev. 57:182-191.

Block, G., B. Patterson, and A. Subar. 1992. Fruit, vegetables, and cancer prevention: A review of the epidemiological evidence. Nutr. Cancer 18:1-29.

Bohm, V. and R. Bitsch. 1999. Intestinal absorption of lycopene from different matrices and interactions to other carotenoids, the lipid status, and the antioxidant capacity of human plasma. Eur. J. Nutr. 38:118-125.

Bohm, V., N.L. Puspitasari-Nienaber, M.G. Ferruzzi, and S.J. Schwartz. 2002. Trolox 
equivalent antioxidant capacity of different geometrical isomers of alpha-carotene, betacarotene, lycopene, and zeaxanthin. J. Agr. Food Chem. 50:221-226.

Botella-Pavia, P., O. Besumbes, M.A. Phillips, L. Carretero-Paulet, A. Boronat, and M. Rodriguez-Concepcion. 2004. Regulation of carotenoid biosynthesis in plants: Evidence for a key role of hydroxymethylbutenyl diphosphate reductase in controlling the supply of plastidial isoprenoid precursors. Plant J. 40:188-199.

Bowen, P., L. Chen, M. Stacewicz-Sapuntzakis, C. Duncan, R. Sharifi, L. Ghosh, H.S. Kim, K. Christov-Tzelkov, and R. van Breemen. 2002. Tomato sauce supplementation and prostate cancer: Lycopene accumulation and modulation of biomarkers of carcinogenesis. Exp. Biol. Med. (Maywood) 227:886-893.

Bub, A., B. Watzl, L. Abrahamse, H. Delincee, S. Adam, J. Wever, H. Muller, and G. Rechkemmer. 2000. Moderate intervention with carotenoid-rich vegetable products reduces lipid peroxidation in men. J. Nutr. 130:2200-2206.

Buescher, R.W. 1979. Influence of carbon dioxide on postharvest ripening and deterioration of tomatoes. J. Amer. Soc. Hort. Sci. 104:545-547.

Buiatti, E., N. Munoz, I. Kato, J. Vivas, R. Muggli, M. Plummer, M. Benz, S. Franceschi, and W. Oliver. 1996. Determinants of plasma anti-oxidant vitamin levels in a population at high risk for stomach cancer. Int. J. Cancer 65:317-322.

Burns, J., P.D. Fraser, and P.M. Bramley. 2003. Identification and quantification of carotenoids, tocopherols, and chlorophylls in commonly consumed fruits and vegetables. Phytochemistry 62:939-947.

Cadoni, E., M.R. De Giorgi, E. Medda, and G. Poma. 2000. Supercritical CO2 extraction of lycopene and beta-carotene from ripe tomatoes. Dyes and Pigments 44:27-32.

Cavalcante, M.L. and D.B. Rodriguez-Amaya. 1992. Carotenoid composition of the tropical fruits Eugenia uniflora and Malpighia glabra. In: G. Charalambous (ed.). Food Science and Human Nutrition. Elsevier, N.Y. pp. 643-650.

Clinton, S.K., C. Emenhiser, S.J. Schwartz, D.G. Bostwick, A.W. Williams, B.J. Moore, and J.W. Erdman Jr. 1996. cis-trans lycopene isomers, carotenoids, and retinol in the human prostate.. Cancer Epidemiol. Biomarkers Prev. 5:823-833.

Collins, J.K., B.H. Arjmandi, P.L. Claypool, P. Perkins-Veazie, R.A. Baker, and B.A. Clevidence. 2004. Lycopene from two food sources does not affect antioxidant or cholesterol status of middle-aged adults. Nutr. J. 3:2-15.

Corazza-Nunes, M.J., M.A. Machado, W.M.C. Nunes, M. Cristofani, and M.L.P.N. Targon. 2002. Assessment of genetic variability in grapefruits (Citrus paradisi Macf.) and pummelos (C. maxima (Burm.) Merr.) using RAPD and SSR markers. Euphytica 126:169-176.

Craft, N.E. 2001. Chromatographic techniques for carotenoid separation. In: R.E. Wrolstad, E.A. Acree, M.H. Decker, D.S. Penner, D.S. Reid, S.J. Schwartz, C.F. Shoemaker, and P. Sporns (eds.). Current Protocols in Food Analytical Chemistry. Wiley, New York. pp. 2.31-2.3.15.

Davis, A.R., W.W. Fish, and P. Perkins-Veazie. 2003. A rapid hexane-free method for analyzing lycopene content in watermelon. J. Food Sci. 68:328-332.

de Ancos, B., E. Gonzalez, and M.P. Cano. 2000 Effect of high-pressure treatment on the carotenoid composition and the radical scavenging activity of persimmon fruit purees. J. Agr. Food Chem. 48:3542-3548

De Pascale, S., A. Maggio, B. Fogliano, P. Ambrosinoana, and A. Ritieni. 2001. Irrigation with saline water improves carotenoids content and antioxidant activity in tomato. J. Hort. Sci. Biotechnol. 76:405-408.

De Stefani, E., P. Boffetta, P. Brennan, H. DeneoPellegrini, J.C. Carzoglio, A. Ronco, and M. Mendilaharsu. 2000. Dietary carotenoids and risk of gastric cancer: A case-control study in Uruguay. Eur. J. Cancer Prev. 9:329-334.

deRigal, D., F. Gauillard, and F. Richard-Forget. 2000. Changes in carotenoid content of apricot (Prunus armeniaca, var Bergeron) during enzymatic browning: Beta-carotene inhibition of chlorogenic acid degradation. J. Sci. Food Agr. 80:763-768

Dewanto, V., X. Wu, K.K. Adom, and R.H. Liu 2002. Thermal processing enhances the nutritional value of tomatoes by increasing total antioxidant activity. J. Agr. Food Chem. 50:3010-3014.

Di Mascio, P., S. Kaiser, and H. Sies. 1989. Lycopene as the most efficient biological carotenoid singlet oxygen quencher. Arch. Biochem. Biophys. 274:532-538.

Djuric, Z. and L.C. Powell. 2001. Antioxidant capacity of lycopene-containing foods. Int. J. Food Sci. Nutr. 52:143-149.

Dumas, Y., M. Dadomo, G. Di Lucca, and P. Grolier. 2003. Effects of environmental factors and agricultural techniques on antioxidant content of tomatoes. J. Sci. Food Agr. 83:369382.

Edwards, A.J., B.T. Vinyard, E.R. Wiley, E.D. Brown, J.K. Collins, P. Perkins-Veazie, R.A. Baker, and B.A. Clevidence. 2003. Consumption of watermelon juice increases plasma concentrations of lycopene and beta-carotene in humans. J. Nutr. 133:1043-1050.

Erdman, J.W. Jr. 2005. How do nutritional and hormonal status modify the bioavailability, uptake, and distribution of different isomers of lycopene? J. Nutr. 135:2046S-2047S.

Erdman, J.W., Jr., T.L. Bierer, and E.T. Gugger. 1993. Absorption and transport of carotenoids. Ann. N.Y. Acad. Sci. 691:76-85.

Fang, Y.Z., S. Yang, and G. Wu. 2002. Free radicals, antioxidants, and nutrition. Nutrition 18:872-879.

Fish, W.W. and A.R. Davis. 2003. The effects of frozen storage conditions on lycopene stability in watermelon tissue. J. Agr. Food Chem. 51:3582-3585.

Fish, W.W., P. Perkins-Veazie, and J.K. Collins. 2002. A quantitative assay for lycopene that utilizes reduced volumes of organic solvent. J. Food Comp. and Anal. 15:309-317.

Fontes, P.R., R.A. Sampaio, and F.L. Finger. 2000. Fruit size, mineral composition and quality of trickle-irrigated tomatoes as affected by potassium rates. Pesq. agropec. bras. Brasilia 35:2125.

Fordham, I.M., B.A. Clevidence, E.R. Wiley, and R.H. Zimmerman. 2001. Fruit of autumn olive: A rich source of lycopene. HortScience 36:1136-1137.

Fraser, P.D., P. Bramley, and G.B. Seymour. 2001 Effect of the $\mathrm{Cnr}$ mutation on carotenoid formation during tomato fruit ripening. Phytochemistry 58:75-79.

Frost and Sullivan Company. European Carotenoids Market. 27 Oct. 2003. http://www.frost. com/Accessed 1 Dec. 2005.

Fukagawa, N.K. 1999. Aging: is oxidative stress a marker or is it causal? Proc. Soc. Exp. Biol. Med. 222:293-298.

Gartner, C., W. Stahl, and H. Sies. 1997. Lycopene is more bioavailable from tomato paste than from fresh tomatoes. Amer. J. Clin. Nutr. $66: 116-122$
German, J.B. 2005. Genetic dietitics: Nutrigenomics and the future of dietetics practice. J. Amer. Diet. Assoc. 105:530-531.

Gianetti, J., R. Pedrinelli, R. Petrucci, G. Lazzerini, M. De Caterina, G. Bellomo, and R. De Caterina. 2002. Inverse association between carotid intima-media thickness and the antioxidant lycopene in atherosclerosis. Amer. Heart J. 143:467-474

Giovanelli, G. and A. Paradiso. 2002. Stability of dried and intermediate moisture tomato pulp during storage. J. Agr. Food Chem. 50:72777281 .

Giovannucci, E. 1999. Tomatoes, tomato-based products, lycopene, and cancer: Review of the epidemiologic literature. J. Natl. Cancer Inst. 91:317-331

Giovannucci, E. 2002. A review of epidemiologic studies of tomatoes, lycopene, and prostate cancer. Exp. Biol. Med. (Maywood) 227:852859.

Giovannucci, E., A. Ascherio, E.B. Rimm, M.J. Stampfer, G.A. Colditz, and W.C. Willett. 1995. Intake of carotenoids and retinol in relation to risk of prostate cancer. J. Natl. Cancer Inst. 87:1767-1776.

Gomez-Prieto, M.S., M.M. Caja, M. Herraiz, and G. Santa-Maria. 2003. Supercritical fluid extraction of all-trans-lycopene from tomato. J. Agr. Food Chem. 51:3-7.

Goodwin, T.W. and M. Jamikorn. 1952. Biosynthesis of carotenes in ripening tomatoes. Nature 170:104-105

Goula, A.M. and K.G. Adamopoulos. 2005. Stability of lycopene during spray drying of tomato pulp. Lebensm. -Wiss. u-Technol. 38:479-487.

Grievink, L., F.G. de Waart, E.G. Schouten, and F.J. Kok. 2000. Serum carotenoids, alphatocopherol, and lung function among Dutch elderly. Amer. J. Respir. Crit. Care Med. 161:790-795.

Hall, C. 1961. The effect of low storage temperature on the color, carotenoid pigments, shelf life and firmness of ripened tomatoes. Proc. Amer. Soc. Hort. Sci. 78:480-487.

Hamauzu, Y., K. Chachin, and Y. Ueda. 1998. Effect of postharvest temperature on the conversion of ${ }^{14} \mathrm{C}$-mevalonic acid to carotenes in tomato fruit. J. Jpn. Soc. Hort. Sci. 67:549-555.

Hartz, T.K., G. Miyao, R.J. Mullen, M.D. Cahn, J. Valencia, and K.L. Brittan. 1999. Potassium requirements for maximum yield and fruit quality of processing tomato. J. Amer. Soc. Hort. Sci. 124:199-204.

Het Hof, K.H., B.C. de Boer, L.B. Tijburg, B.R. Lucius, I. Zijp, C.E. West, J.G. Hautvast, and J.A. Weststrate. 2000. Carotenoid bioavailability in humans from tomatoes processed in different ways determined from the carotenoid response in the triglyceride-rich lipoprotein fraction of plasma after a single consumption and in plasma after four days of consumption. J. Nutr. 130:1189-1196.

Hininger, I.A., A. Meyer-Wenger, U. Moser, A. Wright, S. Southon, D. Thurnham, M. Chopra, B.H. van den, B. Olmedilla, A.E. Favier, and A.M. Roussel. 2001. No significant effects of lutein, lycopene or beta-carotene supplementation on biological markers of oxidative stress and LDL oxidizability in healthy adult subjects. J. Amer. Coll. Nutr. 20:232-238.

Hobson, G.E. 1987. Low-temperature injury and the storage of ripening tomatoes. J. Hort. Sci. 62:55-62.

Hodisan, T., C. Socaciu, I. Ropan, and G. Neamtu. 1997. Carotenoid composition of Rosa canina fruits determined by thin-layer chromatography 
and high-performance liquid chromatography. J. Pharm. Biomed. Anal. 16:521-528.

Holden, A.L., A.L. Eldridge, G.R. Beecher, I.M. Buzzard, S.A. Bhagwat, C.S. Davis, L.W. Douglas, S.E. Gebhardt, D.B. Haytowitz, and S. Schakel. 1999. Carotenoid content of U.S. foods: An update of the database. J. Food Comp. Anal. 12:169-196.

Hornero-Mendez, D. and G. Britton. 2002. Involvement of NADPH in the cyclization reaction of carotenoid biosynthesis. FEBS Lett. 515:133-136.

Horvitz, M.A., P.W. Simon, and S.A. Tanumihardjo. 2004. Lycopene and beta-carotene are bioavailable from lycopene 'red' carrots in humans. Eur. J. Clin. Nutr. 58:803-811.

Isaacson, T., G. Ronen, D. Zamir, and J. Hirshchberg. 2002. Cloning of tangerine from tomato reveals a carotenoid isomerase essential for the production of B-carotene and xanthophylls in plants. Plant Cell 14:333-342.

Ishida, B.K., C. Turner, M.H. Chapman, and T.A. McKeon. 2004. Fatty acid and carotenoid composition of gac (Momordica cochinchinensis Spreng) fruit. J. Agr. Food Chem. 52:274279.

Jones, B.L. and J.W. Porter. 1999. Biosynthesis of carotenes in higher plants. CRC Critical Review Plant Sci. 3:295-324.

Joshipura, K.J., A. Ascherio, J.E. Manson, M.J. Stampfer, E.B. Rimm, F.E. Speizer, C.H. Hennekens, D. Spiegelman, and W.C. Willett. 1999. Fruit and vegetable intake in relation to risk of ischemic stroke. JAMA 282:1233-1239.

Joshipura, K.J., F.B. Hu, J.E. Manson, M.J. Stampfer, E.B. Rimm, F.E. Speizer, G. Colditz, A. Ascherio, B. Rosner, D. Spiegelman, and W.C. Willett. 2001. The effect of fruit and vegetable intake on risk for coronary heart disease. Ann. Intern. Med. 134:1106-1114.

Khachik, F., G.R. Beecher, and M.B. Goli. 1991. Separation, identification, and quantification of carotenoids in fruits, vegetables and human plasma. Pure Appl. Chem. 63:71-80.

Khachik, F., G.R. Beecher, and J.C. Smith, Jr. 1995. Lutein, lycopene, and their oxidative metabolites in chemoprevention of cancer. J. Cell. Biochem. Suppl. 22:236-246.

Khachik, F., L. Carvalho, P.S. Bernstein, G.J. Muir, D.Y. Zhao, and N.B. Katz. 2002a. Chemistry, distribution, and metabolism of tomato carotenoids and their impact on human health. Exp. Biol. Med. (Maywood) 227:845-851.

Khachik, F., F.F. de Moura, D.Y. Zhao, C.P. Aebischer, and P.S. Bernstein. 2002b. Transformations of selected carotenoids in plasma, liver, and ocular tissues of humans and in nonprimate animal models. Invest. Ophthalmol. Vis. Sci. 43:3383-3392.

Kotake-Nara, E., M. Kushiro, H. Zhang, T. Sugawara, K. Miyashita, and A. Nagao. 2001. Carotenoids affect proliferation of human prostate cancer cells. J. Nutr. 131:3303-3306.

Krauss, S., W.H. Schnitzler, J. Grassmann, and M. Woitke. 2006. The influence of different electrical conductivity values in a simplified recirculating soilless system on inner and outer fruit quality characteristics of tomato. J. Agr. Food Chem. 54:441-448.

Kristal, A.R. and J.M. Schenk. 2005. Directions for future epidemiological research in lycopene and prostate cancer risk. J. Nutr. 135:2037S-2039S.

Kucuk, O., F.H. Sarkar, W. Sakr, Z. Djuric, M.N. Pollak, F. Khachik, Y.W. Li, M. Banerjee, D. Grignon, J.S. Bertram, J.D. Crissman, E.J. Pontes, and D.P. Wood, Jr. 2001. Phase II randomized clinical trial of lycopene supple- mentation before radical prostatectomy. Cancer Epidemiol. Biomarkers Prev. 10:861-868.

Lee, H.S. 2001. Characterization of carotenoids in juice of red navel orange (Cara Cara). J. Agr. Food Chem. 49:2563-2568.

Lee, H.S. and G.A. Coates. 2002. Characterization of color fade during frozen storage of red grapefruit juice concentrates. J. Agr. Food Chem. 50:3988-3991.

Leskovar, D.I., H. Bang, K.M. Crosby, N. Maness, J.A. Franco, and P. Perkins-Veazie. 2004. Lycopene, carbohydrates, ascorbic acid and yield components of diploid and triploid watermelon cultivars are affected by deficit irrigation. J. Hort. Sci. Biotechnol. 79:75-81.

Levi, F., C. Pasche, F. Lucchini, and C. La Vecchia. 2001. Dietary intake of selected micronutrients and breast-cancer risk. Int. J. Cancer 91:260-263.

Levy, J., E. Bosin, B. Feldman, Y. Giat, A. Miinster, M. Danilenko, and Y. Sharoni. 1995. Lycopene is a more potent inhibitor of human cancer cell proliferation than either alpha-carotene or beta-carotene. Nutr. Cancer 24:257-266.

Lisiewska, Z. and W. Kmiecik. 2000. Effect of storage period and temperature on the chemical composition and organoleptic quality of frozen tomato cubes. Food Chem. 70:167-173.

Liu, R.H. 2003. Health benefits of fruit and vegetables are from additive and synergistic combinations of phytochemicals. Amer. J. Clin. Nutr. 78:517S-520S.

Lovric, T., Z. Sablek, and M. Boskovic. 1970. Cistrans isomerisation of lycopene and color stability of foam-mat dried tomato powder during storage. J. Sci. Food Agr. 21:641-647.

Matos, H.R., P. Di Mascio, and M.H. Medeiros. 2000. Protective effect of lycopene on lipid peroxidation and oxidative DNA damage in cell culture. Arch. Biochem. Biophys. 383: 56-59.

Mencarelli, F. and M.E. Saltveit. 1988. Ripening of mature-green tomato fruit slices. J. Amer. Soc. Hort. Sci. 113:742-745.

Meredith, F.I. and R.H. Young. 1971. Changes in lycopene and carotene content of 'Redblush' grapefruit exposed to high temperatures. HortScience 6:233-234.

Meydani, M., R.D. Lipman, S.N. Han, D. Wu, A. Beharka, K.R. Martin, R. Bronson, G. Cao, D. Smith, and S.N. Meydani. 1998. The effect of long-term dietary supplementation with antioxidants. Ann. N. Y. Acad. Sci 854:352-360.

Miers, J.C., F.F. Wong, J.G. Harris, and W.C. Dietrich. 1958. Factors affecting storage stability of spray-dried tomato powder. Food Technol. 12:542-548.

Miller, E.C., E. Giovannucci, J.W. Erdman Jr., R. Bahnson, S.J. Schwartz, and S.K. Clinton. 2002. Tomato products, lycopene, and prostate cancer risk. Urol. Clin. North Amer. 29: 83-93.

Mohanty, N.K., S. Saxena, U.P. Singh, N.K. Goyal, and R.P. Arora. 2005. Lycopene as a chemopreventive agent in the treatment of high-grade prostate intraepithelial neoplasia. Urol. Oncol. 23:383-385.

Mohr, W.P. 1979. Pigment bodies in fruits of crimson and high pigment lines of tomatoes. Ann. Bot. (Lond.) 44:427-434.

Mostofi, Y., P.M.A. Toivonen, H. Lessani, M Babalar, and C. Lu. 2003. Effects of 1-methylcyclopropene on ripening of greenhouse tomatoes at three storage temperatures. Postharvest Biol. Technol. 27:285-292.

Muller, K., K.L. Carpenter, I.R. Challis, J.N Skepper, and M.J. Arends. 2002. Carotenoids induce apoptosis in the T-lymphoblast cell line Jurkat E6.1. Free Radic. Res. 36:791-802.

Nguyen, M.L. and S.J. Schwartz. 1998. Lycopene stability during food processing. Proc. Soc. Exp. Biol. Med. 218:101-105.

Oke, M., T. Ahn, A. Schofield, and G. Paliyath. 2005. Effects of phosphorus fertilizer supplementation on processing quality and functional food ingredients in tomato. J. Agr. Food Chem. 53:1531-1538.

Ommen, B.V. and R. Stierum. 2002. Nutrigenomics: Exploiting systems biology in nutrition and health arena. Current Opin. Biotechnol. 13: 517-521.

Opiyo, A.M. and T.J. Ying. 2005. The effects of 1-methylcyclopropene treatment on the shelf life and quality of cherry tomato (Lycopersicon esculentum var. cerasiforme) fruit. Int. J. Food Science and Technol. 40:665-673.

Paetau, I., D. Rao, E.R. Wiley, E.D. Brown, and B.A. Clevidence. 1999. Carotenoids in human buccal mucosa cells after 4 wk of supplementation with tomato juice or lycopene supplements. Amer. J. Clin. Nutr. 70:490-494.

Panasenko, O.M., V.S. Sharov, K. Briviba, and H. Sies. 2000. Interaction of peroxynitrite with carotenoids in human low density lipoproteins. Arch. Biochem. Biophys. 373:302-305.

Patil, B.S. and A. Alva. 2002. Functional components in citrus: Alteration by mineral elements. T.W.Bruulsema and Potash \&Phosphate Institute/Potash and Phosphate Institute of Canada (PPI/PPIC). pp. 1-4.

Patil, B.S., J. Vanamala, and G. Hallman. 2004. Irradiation and storage influence on bioactive components and quality of early and late season 'Rio Red' grapefruit. Postharvest Biol. Technol. 34:53-64.

Peregrin, T. 2001. The new frontier of nutrition science. Nutrigenomics. J. Amer. Diet. Assoc. 101:1306.

Pellegrini, N., P. Riso, and M. Porrini. 2000. Tomato consumption does not affect the total antioxidant capacity of plasma. Nutrition $16: 268-271$.

Perkins-Veazie, P., J.K. Collins, A.R. Davis, and W. Roberts. 2006. Carotenoid content of 50 watermelon cultivars. J. Agr. Food Chem. 54:2593-2597.

Perkins-Veazie, P. and J.K. Collins. 2004. Flesh quality and lycopene stability of fresh-cut watermelon. Postharvest Biol. Technol. 31:159-166.

Perkins-Veazie, P. and W. Roberts. 2003. Can potassium application affect the mineral and antioxidant content of horticultural crops? Amer. Soc. Agronomy, Proc. Symposium on Fertilizating Crops for Functional Food. pp. 2-1-2-6.

Perkins-Veazie, P., J.K. Collins, S.D. Pair, and W Roberts. 2001. Lycopene content differs among red-fleshed watermelon cultivars. J. Sci. Food Agr. 8:1-5.

Pool-Zobel, B.L., A. Bub, H. Muller, I. Wollowski, and G. Rechkemmer. 1997. Consumption of vegetables reduces genetic damage in humans: First results of a human intervention trial with carotenoid-rich foods. Carcinogenesis 18:18471850.

Porrini, M. and P. Riso. 2005. What are typical lycopene intakes? J. Nutr. 135:2042S-2045S.

Portney, L.G. and M.P. Watkins. 2000. Epidemiology. In: L.G. Portney and M.P. Watkins (eds.). Foundations of Clinical Research. Prentice Hall Health, Upper Saddle River, N.J. pp. 317-344

Purcell, A.E., R.H. Young, E.F. Schultz, Jr., and F.I. Meredith. 1968. The effect of artificial climate on the internal fruit color of Redblush 
grapefruit. Proc. Amer. Soc. Hort. Sci. 92:170178.

Raffo, A., G. Malfa, V. Fogliano, G. Maiani, and G. Quaglia. 2006. Seasonal variations in antioxidant components of cherry tomatoes (Lycopersicon esculentum cv. Naomi F1). J. Food Comp. Analysis 19:11-19.

Rao, A.V. 2004. Processed tomato products as a source of dietary lycopene: Bioavailability and antioxidant properties. Can. J. Diet. Pract. Res. 65:161-165.

Re, R., P.M. Bramley, and C. Rice-Evans. 2002. Effects of food processing on flavonoids and lycopene status in a Mediterranean tomato variety. Free Radic. Res. 36:803-810.

Rissanen, T.H., S. Voutilainen, K. Nyyssonen, T.A. Lakka, J. Sivenius, R. Salonen, G.A. Kaplan, and J.T. Salonen. 2001. Low serum lycopene concentration is associated with an excess incidence of acute coronary events and stroke: The Kuopio Ischaemic Heart Disease Risk Factor Study. Br. J. Nutr. 85:749-754

Rodriguez-Amaya, D.B. 1999. Latin American food sources of carotenoids. Arch. Latinoam. Nutr. 49:74S-84S.

Rodriguez-Amaya, D.B. 2001. General procedure and sources of errors in carotenoid analysis. In D.B. Rodriguez-Amaya (ed.). A Guide to Carotenoid Analysis in Foods.. ILSI Press, ILSI Press, pp. 23-31.

Ronco, A., E. De Stefani, P. Boffetta, H. DeneoPellegrini, M. Mendilaharsu, and F. Leborgne. 1999. Vegetables, fruits, and related nutrients and risk of breast cancer: A case-control study in Uruguay. Nutr. Cancer 35:111-119.

Ronen, G., L. Carmel-Goren, D. Zamir, and J. Hirschberg. 2000. An alternative pathway to beta-carotene formation in plant chromoplasts discovered by map-based cloning of beta and old-gold color mutations in tomato. Proc. Natl. Acad. Sci. USA 97:11102-11107.

Ronen, G., M. Cohen, D. Zamir, and J. Hirschberg. 1999. Regulation of carotenoid biosynthesis during tomato fruit development: Expression of the gene for lycopene epsilon-cyclase is down-regulated during ripening and is elevated in the mutant Delta. Plant J. 17:341-351.

Rozzi, N.L., R.K. Singh, R.A. Vierling, and B.A. Watkins. 2002. Supercritical fluid extraction of lycopene from tomato processing byproducts. J. Agr. Food Chem. 50:2638-2643.

Sabio, E., M. Lozano, M. de Espinosa, R.L. Mendes, A.P. Pereira, A.F. Palavra, and J.A. Coelho. 2003. Lycopene and beta-carotene extraction from tomato processing waste using supercritical CO2. Ind. Eng. Chem. Res. 42:6641-6646

Sacks, E.J. and D.M. Francis. 2001. Genetic and environmental variation for tomato flesh color in a population of modern breeding lines. J. Amer. Soc. Hort. Sci. 126:221-226.

Sandmann, G. 2001. Carotenoid biosynthesis and biotechnological application. Arch. Biochem. Biophys. 385:4-12.

Santos, C.A. and P.W. Simon. 2002. QTL analyses reveal clustered loci for accumulation of major provitamin A carotenes and lycopene in carrot roots. Mol. Genet. Genomics 268:122-129.

Sato, R., K.J. Helzlsouer, A.J. Alberg, S.C. Hoffman, E.P. Norkus, and G.W. Comstock. 2002. Prospective study of carotenoids, tocopherols, and retinoid concentrations and the risk of breast cancer. Cancer Epidemiol. Biomarkers Prev. 11:451-457.

Sesso, H.D., J.E. Buring, E.P. Norkus, and J.M. Gaziano. 2004. Plasma lycopene, other carotenoids, and retinol and the risk of cardiovascular disease in women. Amer. J. Clin. Nutr. 79:4753.

Sesso, H.D., S. Liu, J.M. Gaziano, and J.E. Buring. 2003. Dietary lycopene, tomato-based food products and cardiovascular disease in women. J. Nutr. 133:2336-2341.

Sharma, S.K. and M. Le Maguer. 1996. Kinetics of lycopene degradation in tomato pulp solids under different processing and storage conditions. Food Research Intl. 29:309-315.

Shi, J. and M. Le Maguer. 2000. Lycopene in tomatoes: Chemical and physical properties affected by food processing. Crit. Rev. Biotechnol. 20:293-334.

Shi, J., M. Le Maguer, Y. Kakuda, A. Liptay, and F. Nickamp. 1999. Lycopene degradation and isomerization in tomato dehydration. Food Research International 32:15-21.

Soto-Zamora, G., E.M. Yahia, J.K. Brecht, and A. Gardea. 2005. Effects of postharvest hot air treatments on the quality and antioxidant levels in tomato fruit. LWT 38:657-663.

Sozzi, G.O., G.D. Trinchero, and A.A. Fraschina. 1999. Controlled-atmosphere storage of tomato fruit; low oxygen or elevated carbon dioxide levels alter galactosidase activity and inhibit exogenous ethylene action. J. Sci. Food Agr. 79:1065-1070.

Stacewicz-Sapuntzakis, M. and P.E. Bowen. 2005. Role of lycopene and tomato products in prostate health. Biochim. Biophys. Acta 1740:202-205.

Stahl, W., A. Junghans, B. de Boer, E.S. Driomina, K. Briviba, and H. Sies. 1998. Carotenoid mixtures protect multilamellar liposomes against oxidative damage: synergistic effects of lycopene and lutein. FEBS Lett. 427:305308.

Stahl, W., S. Nicolai, K. Briviba, M. Hanusch, G. Broszeit, M. Peters, H.D. Martin, and H. Sies. 1997. Biological activities of natural and synthetic carotenoids: Induction of gap junctional communication and singlet oxygen quenching. Carcinogenesis 18:89-92.

Stahl, W., W. Schwarz, A.R. Sundquist, and H. Sies. 1992. cis-trans isomers of lycopene and beta-carotene in human serum and tissues. Arch. Biochem. Biophys. 294:173-177.

Stahl, W. and H. Sies. 1992. Uptake of lycopene and its geometrical isomers is greater from heat-processed than from unprocessed tomato juice in humans. J. Nutr. 122:2161-2166.

Steinmetz, K.A. and J.D. Potter. 1996. Vegetables, fruit, and cancer prevention: A review. J. Amer. Diet. Assoc. 96:1027-1039.

Steinmetz, K.A., J.D. Potter, and A.R. Folsom. 1993. Vegetables, fruit, and lung cancer in the Iowa Women's Health Study. Cancer Res. 53:536-543.

Strandhagen, E., P.O. Hansson, I. Bosaeus, B. Isaksson, and H. Eriksson. 2000. High fruit intake may reduce mortality among middleaged and elderly men. The Study of Men Born in 1913. Eur. J. Clin. Nutr. 54:337-341.

Surles, R.L., N. Weng, P.W. Simon, and S.A. Tanumihardjo. 2004. Carotenoid profiles and consumer sensory evaluation of specialty carrots (Daucus carota, L.) of various colors. J. Agr. Food Chem. 52:3417-3421.

Tadmor, Y., S. King, A. Levi, A. Davis, and J. Hirschberg. 2004. Comparative fruit coloration in watermelon and tomato. In: L. Dufose (ed.). Pigment Publishing, 400-402.

Takeoka, G.R., L. Dao, S. Flessa, D.M. Gillespie, W.T. Jewell, B. Huebner, D. Bertow, and S.E. Ebeler. 2001. Processing effects on lycopene content and antioxidant activity of tomatoes. $\mathrm{J}$. Agr. Food Chem. 49:3713-3717.
Thompson, K.A., M.R. Marshall, C.I. Sims, S.A. Sargent, and J.W. Scott. 2000. Cultivar, maturity, and heat treatment on lycopene content in tomatoes. J. Food Sci. 65:791-795.

Tomes, M.L. 1963. Temperature inhibition of carotene synthesis in tomato. Botan. Gazette 24:180-185

Tomes, M.L., E.W. Quackenbush, and M. McQuistan. 1954. Modification and dominance of the gene governing formation of high concentrations of beta-carotene in the tomato. Genetics 39:810 817

Torbergsen, A.C. and A.R. Collins. 2000. Recovery of human lymphocytes from oxidative DNA damage; the apparent enhancement of DNA repair by carotenoids is probably simply an antioxidant effect. Eur. J. Nutr. 39:80-85.

Tran, T. and L.C. Raymundo. 1999. Biosynthesis of carotenoids in bitter melon at high temperature. Phytochemistry 52:275-280.

Trudel, M.J. and J.L. Ozbun. 1971. Influence of potassium on carotenoid content of tomato fruit. J. Amer. Soc. Hort. Sci. 96:763-765.

Unlu, N.Z., T. Bohn, S.K. Clinton, and S.J. Schwartz. 2005. Carotenoid absorption from salad and salsa by humans is enhanced by the addition of avocado or avocado oil. J. Nutr. 135:431-436.

U.S. Department of Agriculture, Agric, Research Service. USDA Nutrient Database for Standard Reference Release 18. 2005a. http://www.nal.usda.gov/fnic/foodcomp. Accessed 28 Apr. 2005.

U.S. Department of Agriculture, U.S. of Agr. and Health and Human Services. Dietary Guidelines for Americans 2005b. http://www.health. gov/dietaryguidelines/dga2005/document/ html/chapter5.htm. Accessed 28 June 2005.

van Breemen, R.B., X. Xu, M.A. Viana, L. Chen, M. Stacewicz-Sapuntzakis, C. Duncan, P.E. Bowen, and R. Sharifi. 2002. Liquid chromatography-mass spectrometry of cis- and all-translycopene in human serum and prostate tissue after dietary supplementation with tomato sauce. J. Agr. Food Chem. 50:2214-2219.

Vasapollo, G., L. Longo, L. Rescio, and L. Ciurlia. 2004. Innovative supercritical CO2 extraction of lycopene from tomato in the presence of vegetable oil as co-solvent. J. Supercritical Fluids 29:87-96.

Vogele, A.C. 1937. Effect of environmental factors upon the color of the tomato and the watermelon. Plant Physiol. 12:929-955.

Wei, Y.H. and H.C. Lee. 2002. Oxidative stress, mitochondrial DNA mutation, and impairment of antioxidant enzymes in aging. Exp. Biol. Med. (Maywood) 227:671-682.

Wong, F.F. and G.S. Bohart. 1957. Observations on the color of vacuum-dried tomato juice powder during storage. Food Technol. 11:293-296.

Yeh, S. and M. Hu. 2000. Antioxidant and prooxidant effects of lycopene in comparison with beta-carotene on oxidant-induced damage in Hs68 cells. J. Nutr. Biochem. 11:548-554.

Yen, G.C., L.S. Hwang, and T.C. Lee. 1981. Lycopene from the seeds of ripe bitter melon (Momordica charantia) as a potential red food colorant. J. Chinese Agr. Chem. Soc. 19:227-235.

Young, A.J. and G.M. Lowe. 2001. Antioxidant and prooxidant properties of carotenoids. Arch. Biochem. Biophys. 385:20-27.

Zanoni, B., E. Pagliarini, and R. Foschino. 2000. Study of the stability of dried tomato halves during shelf-life to minimise oxidative damage. J. Sci. Food Agr. 80:1-6.

Zanoni, B., C. Peri, R. Nani, and V. Lavelli. 1999. Oxidative heat damage of tomato halves as affected by drying. Food Research International 31:395-401. 